$$
\begin{aligned}
& \text { Information } \\
& \text { Technology } \\
& \text { \& Politics } \\
& =
\end{aligned}
$$

\title{
The role of gender in online campaigning: Swedish candidate's motives and use of social media during the European election 2014
}

\begin{tabular}{|r|l|}
\hline Journal: & Journal of Information Technology \& Politics \\
\hline Manuscript ID & WITP-2016-0069.R2 \\
\hline Manuscript Type: & Research Paper \\
\hline Keywords: & Social Media, Gender, Election Campaign, European Election, Twitter \\
\hline \multicolumn{2}{|c}{} \\
\hline
\end{tabular}

\section{SCHOLARONEm}

Manuscripts 


\section{Introduction}

Social media can provide candidates better control over their self-images and public narratives. As a result, candidates have altered their campaign tactics to avoid the filtered interpretation of campaign messages released through traditional media outlets (Gainous and Wagner, 2013). Even as social media is increasingly integrated into election campaigning, the question of what it signifies for politicians to be active online remains largely unanswered. This is especially true for female candidates.

Because individual candidates can influence public perception through strategic use of social media, such media might be a particularly useful tool with which women candidates can counteract masculine communication norms in politics (Meeks, 2013). The possibility of direct communication and interaction with voters and followers may also be particularly compelling to women who wish to avoid the images given to them by traditional media, which is generally less favorable to female candidates (Heith, 2003; Jalalzai, 2006; Kahn, 1996). In this regard, social media could provide a means to strengthen women candidates by presenting new opportunities to reach out, mobilize voters and target particular groups, such as young women. There are, however, very few studies that explicitly explore gender-based differences in social media use, rather than simply including gender as a control variable in the uptake of online campaign tools. We therefore know very little about the contours of gendered differences, both in terms of motives and actual use. Moreover, most of the studies concerning online campaigning have been conducted in Anglo-American contexts (Hermans and Vergeer, 2012; Jungherr, 2014), where the political systems are more candidate-oriented and female politicians are quite few.

In this study, we test the relationship between gender and candidate approaches to social media campaigning by exploring a party-oriented system with a strong presence of female 
politicians, namely Sweden. Women have been present in politics and parliament for a long time in Sweden, and gender equal political representation is the norm rather than an unievable ideal. Exploring gendered campaign strategies and practices in this relatively gender equal political setting allows us to test whether there is a difference between the motives behind and use of social media platforms for campaigning purposes by male and female candidates, even in a seemingly gender equal context. Moreover, Sweden provides an interesting case for examining candidates' use of social media in general, since Swedish parties and candidates stand out as early adopters and the most extensive users of web technologies (Vergeer, Hermans and Cunha, 2013).

Additionally, most studies concerning the factors driving web campaigning do not account for individual attitudes and subjective assessments of the value of online platforms as campaign tools. Previous research findings have also confirmed a discrepancy between the intention to use web campaigning and the actual adoption (Marcinkowski and Metag, 2014; Segaard and Nielsen, 2013). By combining survey data with data regarding how candidates actually use social media, we expected to gain a deeper insight into the factors that drive the use of social media for election campaigning. When considering types of activity on Twitter, we also used three time periods to capture the candidates' behavior during non-campaign periods, whereas most studies have concentrated only on the campaign period surrounding elections when assessing the online behavior of politicians (Larsson, 2015a).

The paper will proceed as follows. First, we discuss candidates' use of social media during election campaigns and the possible impact of this use. Second, we discuss research concerning gendered campaigning practices, emphasizing the online environment. Thereafter, we 
discuss Sweden as a case for studying gender and online campaign practices together with data and design. Finally, we discuss our results and their implications.

\section{Social media and personalized campaigning}

The mediatization of politics and the arrival of social media coincide with a development toward individualized campaigning, in which a more personal communication style has become advantageous (see Bimber and Davis, 2003; Strömbäck, 2008; Vergeer and Hermans, 2013). The characteristics of social media provide individual politicians with new opportunities for personal campaigning and political communication. The individual politician can easily adopt social media as a campaign tool and the opportunities for more personalized campaigning through social media can be expected to increase even within party-centered systems (Enli and Skogerbø, 2013; Karlsen, 2011), such as Sweden.

In addition to bypassing media filters and journalistic frames, advantages for individual politicians include opportunities to make statements about different events, add interpretations or make comments (Gainous and Wagner, 2013). Furthermore, politicians might have other advantages in addition to accessibility through social media for individual campaigning; experimental research has shown that engagement with voters online also leads to positive evaluations of politicians (e.g., Grant, Moon and Grant, 2010; Utz, 2009; Vergeer and Hermans, 2013). Politicians who use a more interactive communication strategy can additionally obtain a larger number of followers (Lilleker and Koc-Michalska, 2013), which in turn can redistribute content. The effects of social media interactivity in political campaigns, such as exposure to comments, can conversely shape both positive and negative perceptions of candidates (Brewer et 
al., 2015), suggesting that it is important for politicians to control the content on their social media profiles.

Because it gives control over messages and strategies, social media may work particularly well for female candidates, who are often unelected or have junior status and, therefore, are less likely to be constrained by having to conform to the party message (European Parliament, 2013). For female candidates in particular, social media can also allow the contradiction of pertinent gender stereotypes, such as negative appraisals of issue competencies, in voter evaluations (Dolan, 2010). The potential benefits will be discussed further in the next section, along with previous research concerning gender and campaigning, as well as previous studies on candidates' use of social media.

\section{Gender representation as a function of the equalization perspective}

The arrival and amplified use of social media as an interactive, open and transparent platform has raised questions of its democratizing potential. A main issue to be addressed is whether new technologies can improve democratic processes by allowing interaction among candidates, parties and voters, or by organizing election campaigns in less costly and more direct ways (Gainous and Wagner, 2013). According to the equalization theory (Barber, 2001), the use of the internet helps remove barriers that favor some groups and individuals in the electorate, and in this view, online platforms can provide a means by which people and politicians gain more opportunities for interaction (Barber, 2003; Hagen and Mayer, 2000). In contrast, research has shown that use of the internet and new technology is being normalized into the current electoral paradigm to be used as a part of the conventional political structure (Bimber and Davis, 2003; Hindman, 2008; Ward, Gibson and Lusoli, 2003). Normalization theory states that actors who already have the most influence will most likely to benefit from new online campaign methods 
(Margolis and Resnick, 2000). Parties that have more resources would, in this view, afford more professional campaigns and social media would be used as just another channel, causing no disruption to traditional patterns in offline politics (Lilleker et al., 2011).

Overall, the literature suggests that different functions of normalization apply for patterns of website adoption as compared to social media, which offers some evidence to refute normalization (Southern, 2015). Minor parties, for instance, appear to be more effective in gaining votes through social media than through the adoption of personal websites (Gibson and McAllister, 2015). It is possible that given time, the differences in social media use compared to other web platforms will even out. It could be argued, however, that specific attributes of social media would be more beneficial for minor parties or lesser-known candidates. One difference, and perhaps advantage, would be the interactive attributes of social media and the possibilities of actively building a personal platform through which candidates could more efficiently reach out to voters and media, as opposed to webpages and similar platforms.

Although the definition of normalization as a concept tends to lack specificity (Southern, 2015), party size, campaign budget and incumbency often serve as measures to indicate whether potentially weaker parties or candidates can gain favor through web-based campaigning (Vaccari, 2013). Lusoli (2005) suggested that the influences of internet use on women candidates' chances of electoral success, or lack thereof, should also be thought of as functions of normalization. The same logic applies to social media use by underrepresented or politically marginalized groups, such as women and ethnic minorities (Jacobs and Spierings, 2016).

As the term "equalization" in this context often refers to social media giving opportunities to minor parties or lesser-known candidates, the new opportunities it could provide 
to female candidates would, in a similar way, be an indication that social media upsets traditional campaign dynamics or breaks traditional patterns of gender representation. Thus, gender representation can also be thought of as a function of equalization. Flowing from the same line of reasoning, differences in internet-based campaigning that show male advantages and overrepresentation would subsequently indicate a normalized pattern. Perceived male bias during elections would, from this perspective, result in women candidates using the platform over which they have the most control. If women are perceived as being portrayed disadvantageously by editorial media, this would also speak in favor of using alternative campaign strategies. In a relatively gender equal context such as Sweden, equalization in terms of new campaign possibilities for women candidates can be seen as a way for women to avoid gendered perceptions that continue to persist. A lack of difference in social media use would, in this context, suggest that men and women are campaigning under relatively similar terms.

Research on web-based campaigning and candidates' use of social media has, to a very limited extent, examined the role or function of gender. The literature concerning gender and representation has likewise not examined if and how gender has an impact on online practices and strategies. This article provides a first attempt to test the perseverance for gendered campaign strategies online by studying a context where the conditions for campaigning are relatively equal between male and female candidates. Below, we will develop our discussion of Sweden as a case, in the context of the European elections. Prior to that, the literature on gender and campaigning will be discussed, as well as literature concerning candidates' use of online platforms and social media in particular.

\section{Gender and campaign practices}


There remain substantial gender differences in modern democracies pertaining to representation, although women generally perform as well as their male counterparts in similar types of electoral races (Darcy, Welch and Clark, 1994). Recent research has found little evidence to support previous claims that voters employ gender stereotypes when they evaluate women candidates (Dolan and Lynch, 2016). Furthermore, no financial disadvantages appear to constrain women candidates in particular (Hogan, 2007; Werner, 1997). A great issue involved in increasing the positions of women to elected office remains the significant lack of female candidates. In general, gender affects the decisions of women and men to run for office based on their personal perceptions of capability. In the United States, for instance, women are more likely to doubt their abilities to engage in the campaign process (Fox and Lawless, 2011). Although research has shown that women are equally supported in elections when they run, this is not necessarily because they are treated equitably by the electorate. Instead, it could depend on their political quality; that is, women who do run must be even better candidates to be equally competitive with male contenders (Fulton, 2012; Pearson and McGhee, 2013).

Gender differences related to campaign behavior, in particular, have largely focused on the different issues addressed during the campaign. In previous studies, candidates' genders were, to some extent, related to the issues on which they focused (e.g., Dabelko and Herrnson, 1997; Larson, 2001). Later research does not, however, offer any support that female candidates would focus on different issues than would male candidates, or that there exist a particular set of gender-stereotyped issues, like social issues (Dolan, 2005). There appear to be few gender differences persistent in overall campaign behavior and the use of varying campaigning tools. For example, similarities tended to outweigh the differences between male and female candidates in the way they are presented in television advertisements (Sapiro, Walsh, Strach and Hennings, 
2011). Much less is known, however, concerning the extent to which male and female candidates use different communication strategies during their campaign or differ in motives for using those strategies. Nonetheless, it is during the campaign that a candidate can choose how to present themselves and their political agenda, as well as choosing how to communicate with voters, which later forms the basis of their representation.

For the overall uptake of online campaigning by candidates, important factors include party size, competitiveness, challenger versus incumbent position, and age (Gulati and Williams, 2013; Larsson and Kalsnes, 2014; Lassen and Brown, 2011; Strandberg, 2013; Vergeer, Hermans and Sams, 2011). Existing research indicates that younger candidates belonging to minor parties and coming from challenger positions are more likely to use social media.

Some studies conducted in the early years of online campaigning using websites indicated that gender would generate similar campaign approaches online (e.g., Carlson, 2007), whereas others did not. Women candidates have, for instance, been found to be more likely to use blogs in their campaign and also to utilize a broader range of blogging practices, such as interactive features (Carlson, Djupsund and Strandberg, 2014). The role of gender in relation to uptake of social media in particular, has proven to be important in some studies. Gender had an impact in a study by Jackson and Lilleker (2011), which found that female British MPs were overrepresented on Twitter, compared to their numbers in Parliament. A study of Twitter use by the House candidates in the 2012 campaign also found that women were more likely to use Twitter (Evans, Cordova and Sipole, 2014). In contrast, gender has proven to be a statistically nonsignificant factor for online presence and adoption by candidates running in the European Parliament elections or by the members of European Parliament (Vergeer et al., 2013; Larsson, 2015a). 
Few studies look beyond activity level to variation in actual use, but there are some exceptions. Research conducted in the United States shows that female politicians use Twitter more intensely than do male politicians, have significantly more followers and differ in their manners of using social media, in terms of content of messages and issues covered. Women were more likely to use "attack tweets", and used campaign, issues or mobilization tweets more often. Male candidates were slightly more likely to use personal tweets. Overall, the findings suggest that women use Twitter more actively as a campaign tool (Evans et al., 2014). In contrast to these findings, Just and Crigler (2014) reported a lack of gender difference in relation to some of the above measures. Candidates tended to be as active, focus on similar topics and use similar tone. They did, however, find significant gender differences in the social aspects of social media use, in the way that women connected more positively with followers. In an analysis of state legislators on Twitter, party and gender effects interacted; specifically, non-Republican women mentioned family somewhat more often than did non-Republican men, but within the group of Republican legislators, women were much less likely to talk about family (Cook, 2016).

Although research concerning the effect of candidate gender is inconclusive, gender does appear to be an important variable in politicians' use of social media platforms. It would be premature to declare that gender is irrelevant in newer forms of online campaigning, but it is also a demanding task to study, as social media, such as Twitter, is a moving target, and observed patterns in one election could look very different in the next. Furthermore, the different national electoral systems matter for representatives' social media use in Europe (Obholzer and Daniel, 2016). Below, we will discuss the European elections as a particular case for studying online campaigning, as compared to national elections.

\section{European Parliament elections}


Previous research controlling for gender when measuring uptake and level of activity on social media has mainly looked at politicians who were already holding office. The outcome may be different for challenger candidates, particularly in European elections, in which fewer established candidates run compared to national elections. Women are in general more successful in the European election compared to national elections, because national political parties view these elections as having less at stake and thus are willing to nominate more women or other, less traditional candidates (Freedman, 2002; Harrison, 2005).

The logic of political competition varies across national and European elections, with the latter often referred to as second-order national elections (see Schmitt, 2009). Although the positive effects of this second-order setting for small parties are well known, the implications for independent candidates have rarely been discussed (for an exception, see Ehin and Solvak, 2012). There are a number of reasons, however, why independent or non-incumbent candidates may benefit from running in European Parliament elections. For example, in this electoral context, the individual candidates' campaigns are less dependent on the party and the campaign organization. This can be especially rewarding for less-established (female) candidates. The European (second-order) election may therefore provide more variation in personal campaign strategies across parties and candidates than do (first order) national elections, where individual candidates' campaigns are more dependent on party organization. Lesser-known candidates would also struggle more to gain traditional media attention.

\section{Sweden as a case}

In this study, we see Sweden as a critical case because female politicians are nearly as prevalent as male politicians in the representative assemblies. For more than 20 years, female politicians have made up at least 40 percent of all three elected levels of representative assemblies (local, 
regional and national). In the government, there has been equal representation of men and women since 1994 (Krook, 2006). The importance of gender-related issues is also salient in the Swedish debate (Wängnerud, 2015). In a comparative European perspective, Sweden has an equal distribution of representatives in the European Parliament (out of 20 seats, 11 went to female legislators). Moreover, in the 2014 European election, a pronounced feminist party, Feminist Initiative, made it into the Parliament with one seat.

Sweden has a fairly typical party-centered European political structure, in which the members of local and national assemblies are loyal party representatives (Gilljam, Karlsson and Sundell, 2010). Sweden uses a list system, whereby candidates are placed on the list according to party selectors, and the higher they are on the list, the greater are their chances of being elected (Pierre, 2015). The candidates do have an incentive to cultivate personal votes, however, as a candidate who receives five percent of the party's votes can "break" the list. Nonetheless, this semi-open list system does not change much. For example, in the 2014 election, only one candidate became an MP due to personal votes (Berg and Oscarsson, 2015). The political parties are therefore central actors in the success of an aspiring candidate. We know from previous research that in strong party systems, the party leadership stands a better chance of ensuring that their representatives share the party's preferences than they do in more candidate-oriented systems (Müller, 2000). The leeway for individual candidates to cultivate their own relationships with voters is therefore more restricted.

Taken together, the high numbers of women politicians in the Swedish system and their activities within a strong party system, in which individual candidates' actions are centered on party interests, make gendered findings less plausible. Nonetheless, gendered perceptions can be expected to be preserved even when representation is equal in numbers. For instance, women in 
the legislature tend to speak less on "harder" policy issues than do men in Sweden (Bäck, Debus and Müller, 2014). Furthermore, a recent study on Swedish municipal politicians revealed that gender inequalities continue to obstruct women from political power, due to the so-called "glass ceiling effect" (Folke and Rickne, 2016). The gender-related patterns we may discover in this study should be relevant in contexts where female politicians are less common and where individual politicians have more pronounced roles to play during the election campaign, even though Sweden is a relatively gender equal case. Women should, according to this argument, be even more motivated to use social media in other modern democracies with less female representation.

Studying gender-based differences in campaign behavior in Sweden can improve our understanding of whether increased gender equality in representation cultivates new behavior, to the extent that male and female politicians behave fairly similarly, or if gendered campaigning is something more fundamental, and typical male and female behavior among political candidates continues to exist even in gender-equal contexts. Against the backdrop of a development towards personalized campaigning and the interactive features brought forward by social media, we address the following three questions:

1. Do women candidates consider social media to be a more important campaign tool than do male candidates?

2. Are female politicians more likely to use Twitter to enhance the political messages of their party or their personal agendas?

3. Will women politicians behave differently than male politicians on Twitter by being more active and communicating more interactively? 


\section{Data material and methods}

This study used the Swedish candidate survey of candidates running for the 2014 European election. The survey contained questions regarding the importance of different campaign activities, motives for Twitter use and evaluation of the candidates' use of Twitter. Previous research has found two main styles of social media campaigning: a party-centered and an individualized style (Karlsen and Enjolras, 2016). Female politicians in general are more concerned about representing the party than representing themselves, when compared to men (Scully and Farrell, 2003). In the survey, we therefore asked questions concerning the dimension of a personal versus party-centered communication style. The questions on motives also covered other aspects of uses for political purposes, such as whether the primary audience consisted of media, politicians or voters. In the survey, we asked how important Twitter was in terms of the following: communicating the politician's individual daily activities, sharing information about the party's daily activities, displaying a more personal side, contacting voters personally, highlighting personal views, highlighting the party's position, debating with political opponents, criticizing political opponents, reaching as many voters as possible and making an impact in traditional media (see questionnaire in Appendix 4).

In terms of gender and online campaigning, social media can potentially offer both opportunities and challenges for female candidates. As women are more likely to be exposed to the risk of online harassment and trolling (see Megarry, 2014), this could, for instance, hamper the use of social media platforms for female candidates. We therefore also asked the candidates why they did not use social media, and if the risk of harassment would be one reason not to do so. 
To analyze the candidates' actual Twitter use, we collected data on Twitter activity during three time periods for candidates with Twitter accounts. These time periods included the campaign period (April-May 2014), a pre-campaign period (February 2013) and a period after the election (January-March 2015). From the Twitter accounts, we collected the number of tweets sent, number of @ mentions, retweets, number of tweets with hashtags (\#) and number of tweets containing links.

The questionnaire, a web survey, was sent out directly after the 2014 election to all 315 candidates from the main political parties. The response rate was 46 percent (see Appendix 3 for response rate per party, age group and gender in the survey). In the models, we controlled for age, incumbency, placement on the party list, political party and seniority (whether or not they had been members of the national parliament). These variables had all proved to be important in various previous studies, although their importance was not entirely consistent throughout the different contexts. For social media uptake and use, age was the one factor that stood out as being most significant (Larsson, 2015a; Lassen and Brown, 2011; Vergeer and Hermans, 2013). Electoral vulnerability had no effect on uptake according to Lassen and Brown (2011), and Strandberg (2013) reported incumbency to be positively correlated with social media use. In many other cases, challenger candidates employed social media to a larger extent (Druckman, Kifer and Parkin, 2007; Gibson, Lusoli and Ward, 2008; Jackson and Lilleker, 2009). According to a later study of the European 2014 election by Obholzer and Daniel (2016), MEPs at risk of losing their seats are more active on Twitter. Moreover, previous studies have shown that seniority has an impact on activity on Twitter. Senior MPs are in general more active users (Jackson and Lilleker, 2011). 
Party size is sometimes used as a measure of how resources influence uptake of social media; the larger the party, the more resources are available. For example, Lilleker and KocMichalska (2013) found that MEPs from minor national parties perform better for different categories of online campaigning. In addition to party size, the ideological nature of the parties must be considered if we want to explain uptake and use of social media. Party ideology was unrelated to adoption of Twitter as a campaign tool according to Vergeer and Hermans (2013); however, in a more recent study of candidates in the EU elections of 2014, party belonging was important. There was a higher likelihood that candidates belonging to mainstream parties would use Twitter as opposed to more extreme party candidates, on an economic left-right scale (Nulty, Theocharis, Popa, Parnet and Benoit, 2016). The more extreme candidates are on the GreenAlternative-Libertarian vs Traditional-Authoritarian-Nationalist (GAL/TAN) dimension, however, the more often they use Twitter (Obholtzer and Daniel, 2016). In Sweden, the Feminist Initiative party and the Sweden Democrats are on the opposite ends of the GAL/TAN scale. Based on a study of the parties' official social media accounts, the Feminist Initiative party was among the most active, whereas the Sweden Democrats, on the contrary, were among the least active (Larsson, 2015b). For this reason, we also controlled for party affiliation.

\section{Dimensions in campaign activities}

The empirical section begins with a description of how the candidates assessed the importance of social media platforms, such as Facebook and Twitter, in relation to other campaign activities. The survey covered 18 campaign activities, and the candidates ranked these from unimportant to very important on a 5-point, Likert-type scale. Respondents ranked Facebook as the third most important activity; 84 percent of the candidates used it, 67 percent of which indicated that it was of importance to their campaign (Figure 1). Respondents ranked Twitter as the sixth most 
important, with 65 percent of candidates using it, 38 percent of which reported it to be important. Other web-related activities, such as individual blogs and webpages, were seen as less important compared to social media channels. All in all, although social media platforms were not the most important campaign aspects, Facebook and Twitter were within the upper third of the most important campaign activities.

\section{[Insert Figure 1 here]}

To study the relationship between the importance of social media and gender, we employed a factor analysis (principal-component). The results yielded five dimensions of campaign activities (see Appendix 1). Social media (i.e., Twitter, Facebook, blogs and webpages) emerged as a distinct factor (Cronbach's alpha $=0.73$ ). These activities were all related to the candidates' online presences. Other factors were related to what we termed either traditional campaign activities (spreading the party's campaign material, meeting with party groups, contacting media and making public speeches; Cronbach's alpha $=0.70$ ), outreaching activities (calling voters, visiting workplaces and organizations, or communicating through individual email lists or SMS; Cronbach's alpha =0.67), personal activities (visiting door-todoor, putting up individual election posters or sending letters to voters; Cronbach's alpha $=0.65$ ) and media activities (releasing individual advertisements in newspapers, radio and television channels, cinemas or individual election pamphlets; Cronbach's alpha $=0.67$ ).

When analyzing these dimensions and their relationships to gender, we found that women candidates overall tended to place greater value on all campaign activities than did male candidates (Table 1). Out of five different campaign activities, female candidates assessed three as significantly more important than did men. Among these were activities on the web (mean for 
female candidates was 0.47 , mean for men was 0.36$).{ }^{1}$ It is of interest that female candidates assessed more activities as important. One of the reasons why female candidates see more activities as important may be related to the fact that women think that more activities are necessary to pursue a political career (Fox and Lawless, 2011). This tendency to stress that more things are important, even in a gender-equal context, could partly explain why women in less equal contexts are reluctant to step forward as candidates; in other words, female candidates assess that an electoral campaign demands more of them than it does of men.

Among the individual control variables, we cannot see that there exists the same type of consistent pattern as there was between male and female candidates, with the exception of age. Younger candidates see web campaigning as more important than do their older colleagues, whereas the opposite is true when it comes to traditional campaigning, where older candidates stress its importance. It is worth mentioning that web-campaigning is the only thing that the incumbents assessed as more important than did the other candidates, which is in line with Strandberg's results. Strandberg (2013) suggested that a reason for this could be that journalists' use of social media as a news source would favor more established candidates.

If we study the importance of party affiliation and the candidates' assessments, it is evident that Sweden Democrat candidates assessed all campaign activities as less important than did candidates from other parties. We cannot offer a solid explanation for this finding. The Sweden Democrats had their best election results ever, so it would be natural to assume that they would be very optimistic about the usefulness of their activities, but that is not the case. It remains plausible that the attitude stems from their status as an anti-establishment party, and that

\footnotetext{
${ }^{1}$ All the means in the article were calculated with the margins command in Stata 14.1, while holding other factors constant at their average values.
} 
the candidates feel stigmatized by the editorial mainstream media and the parliament's current cordon sanitaire around the party. This appears to also affect how they view social media, something we will discuss further below.

\section{[Insert table 1 here]}

In looking at each of the activities related to social media and web-based campaigning, there was a significant gender difference for Twitter, where women assessed Twitter as more important than did men. Nearly half of the women (49 percent) assessed Twitter as "rather important" or "very important", whereas among the men, the corresponding number was only 28 percent. We can also see the same pattern emerging in Table 1. The tendency for female candidates to assess all activities as more important than did men is present as well (if we collapse the four variables into one, there is a significant gender difference). The only other significant result was found for Facebook, which was in fact even more important for women; 76 percent of the female candidates saw Facebook as rather or very important, whereas 58 percent of male candidates felt the same.

For the control variables, list placement had no effect on any campaign activity. Age was significant for Twitter use (as supported by previous research); older candidates were less optimistic about its usefulness. Incumbents assessed Twitter as more valuable than did the other candidates. Among the party variables, the two most interesting significant and non-significant results were from the Sweden Democrats and the Feminist Initiative. During the election campaign, the Sweden Democrat candidates and their activities on social media were scrutinized by the media. Some of these candidates even had to resign as a result of this public scrutiny. It is therefore interesting to note that candidates from the Sweden Democrats were slightly more 
skeptical about the usefulness of social media. In contrast, the Feminist Initiative candidates based their campaigns to a large extent on social media (Blombäck and de Fine Licht, 2015) and were the most active on various social media platforms. The Feminist Initiative party also had more followers than any of the other parties, but Feminist Initiative respondents did not assess Twitter and Facebook as crucial tools for their success. The results here do not support previous research in which candidates from more extreme parties on the GAL/TAN scale used social media more extensively.

It has been theorized that social media not only allow disadvantaged parties and candidates to bypass traditional media, but may also serve populist parties as they strive to appeal to "common people" by offering direct contact opportunities for this aim (Jacobs and Spierings, 2016). Conversely, populist radical right parties like the Sweden Democrats are often organized around strong leaders who personify the party and seek to control the party as a whole. As these parties are more centralized, this control decreases as a result of social media (Jacobs and Spierings, 2016). The less-motivated candidates in the Sweden Democrats could therefore, in addition to being affected by tough media coverage, also be the result of a more centralized control over candidate behavior. ${ }^{2}$

In summary, the results shown in Table 1 and Table 2 help us to answer our first question, suggesting that women candidates consider social media to be a more important campaign tool than do male candidates. There is a tendency, however, for women candidates in general to assess all campaign activities as more important.

\footnotetext{
${ }^{2}$ In the party's ethical guidelines from 2011, there are instructions for social media use that state that it is important to be honest and sincere, and treat people the same way on the Internet as in real life. Among other things, the guidelines state that candidates should: not use social media when in an upset state of mind, always think about the political consequences when publishing, avoid internal discussions (the guidelines say this is best handled within the party) and respect the law (pages $5-6$ ). These statements give a clue as to some of the trouble the party has had with their representatives on social media platforms.
} 


\section{[Insert table 2 here]}

\section{Motives for Twitter use and evaluation}

In the survey, we asked whether the candidates prioritized using Twitter for individual or partycentered purposes. To measure Twitter's usefulness for individual campaigning practices, we constructed an index based on three questions that asked the candidates to assess the importance of using Twitter for the purposes of (1) displaying a relatable personal side of themselves, (2) getting in personal contact with voters and (3) making their personal views visible (Cronbach's alpha $=0.85)$. To measure Twitter's usefulness to party-centered campaign approaches, the candidates were asked about the extent to which their Twitter usage was important for (1) spreading information about the party's daily activities and (2) making the party's views visible $($ Cronbach's alpha $=0.81)$. The different sets of questions were merged into party-centered and personal-centered categories. In the questionnaire, the scale runs from 1 "to a very small extent" to 7 "to a very large extent"; in the analyses, however, the items are merged into two indices that range between 0 "to a very small extent" and 1 "to a very large extent".

There was, in fact, a significant difference between male and female candidates in terms of motivations for using Twitter to expose themselves as candidates (Table 3). The mean for women candidates was 0.63 and for men was 0.51 . At the same time, more female than male candidates stated that they used Twitter to draw attention to their parties (the mean for women was 0.68 , mean for men was 0.50 ). This result is again in line with what we found earlier. Women candidates stress more aspects as being important in their campaign than do men, and as a consequence, Twitter is more important for women, both personally and also for their party. 
The control variables did not offer much variation. In fact, gender was the only consistent pattern for the party-centered model.

When women candidates evaluated their party-centered uses of Twitter, they were also more positive than male candidates (Table 3). The results indicated that women candidates use Twitter as a professional campaign tool more often than do men, and these findings strengthen the picture that emerged above: women candidates value Twitter as more important in their campaign efforts than do male candidates, as a way to reach out to voters with the party message (mean for women was 0.53 , mean for men was 0.40 ). In their evaluation of how well they performed with their personal usage of Twitter, however, women were not significantly more satisfied than were men (mean for women was 0.45 , mean for men was 0.40 ). Since the number of respondents was limited, it is difficult to further investigate the difference between how male and female candidates evaluate their success in bringing forward their personalized campaign. We can only observe that the difference between male and female candidates' motivations for using Twitter was 0.12, whereas when they assessed their success of forwarding their personalized campaign, the difference remained at 0.5 . This could be another indication that women put more pressure on themselves on the campaign trail.

To answer our second question of whether or not female politicians are more likely to use Twitter to enhance the political messages of their party or their personal agenda, we have seen that female candidates actually work harder than men to promote both themselves and their parties. We understand this tendency to be an indication of gendered campaigning. 


\section{[Insert table 3 here]}

The presence of incivility can have hampering effects for online political discourse (Gervais, 2015), yet it was not an issue reported by the candidates in our survey. When we asked the respondents who did not use Twitter about their reasons for refraining from doing so, only one male and one female candidate stated that they do not use Twitter because they "do not want to be exposed to personal harassment."

To evaluate the candidates' actual usage of Twitter (see Table 4), we collected tweets from all the Swedish candidates active on Twitter during the 2014 election campaign (between March 25 and May 25). To detect any special campaigning effects, we also collected tweets from the candidates one year before the election (February 2013) and again after the election (January to March 2015). In order to explore differences in actual use and activity between male and female candidates, we collected the number of tweets and the use of retweets, mentions, hashtags and links. Both retweeting and mentioning can indicate a more interactive style of use, whereas the use of links and hashtags indicate intention to contribute to a debate on an issue at hand or provide further information on topics such as campaign issues. To separate the different uses of Twitter, we created two variables: Twitter interactions (consisting of retweets and mentions) and Twitter information (consisting of links and hashtags). Future studies into communication practices, however, may benefit by taking a more granular approach to different uses based on disaggregate links, hashtags, retweets and @ replies. Examining the contents of tweets and a possible gendered communication style would also be of interest. In this article, we restricted our scope to a variable for the total number of tweets that candidates sent out. Because our 
measurements consist of count data with the existence of overdispersion, we used negative binomial regression in our models. ${ }^{3}$

There were no gender differences for either numbers of tweets or Twitter activity during the election campaign (Table 4). Although there was a tendency for women to be more active, the difference was not significant. There were, however, some significant effects in the model. Older candidates were less active on Twitter, tweeting, interacting and sharing information to a lesser extent than did younger candidates. The same tendency was evident among candidates who were lower ranked on the party list. We correspondingly observed that incumbents were more active on Twitter in comparison to the other candidates; here, it also appears that seniority matters. Candidates who had been members of the national parliament used Twitter to a higher extent. It is difficult to speculate why, but one explanation could be related to party loyalty, as when the election was over and a year had passed, the more senior candidates were no longer more active on Twitter.

The effects of election campaigning were further evident for other candidates' activities a year later. Female candidates were more active on Twitter and also had more interactions with their followers. The difference between male and female candidates who shared Twitter information was nearly significant, as well. It appears that gender is relevant, but not when it is election time. The competition between the candidates makes gender less important during the election campaign than it is before or after the campaign. When the competition is over, however, women candidates are more interested than men in communicating with their followers. This result was not driven by the intensity during the election campaign. In the 2014 election

\footnotetext{
${ }^{3}$ Because alpha was significantly different from zero, we preferred negative binomial regression over Poisson regression.
} 
campaign, the candidates tweeted nearly 38,500 times, and in the three first months of 2015, they sent more than 40,500 tweets. To further validate the results, we also looked at the candidates' activities a year before the election (February 2013). Here, we found the same pattern: women candidates were more active than men on Twitter (see Appendix 2). These results underscore the relevance of studying what politicians are doing between elections, not only what they are doing during campaigns (Esaiasson and Narud, 2013).

Among the other variables, we observed that higher-ranked candidates used Twitter more often even when the election was over. Similarly, younger candidates tweeted more and had more interactions than did their older colleagues. Incumbents were also more active. There were no larger discrepancies between the parties, however, other than candidates from the Center Party being more active than the other party candidates after the election.

\section{[Insert table 4 here]}

\section{Conclusions}

In this study, we examined the importance of gender in how political candidates use social media for campaigning purposes. Using survey data on Swedish candidates and behavioral data from Twitter during the 2014 European election, we found gender-related patterns in the level of value candidates placed on social media as a campaign tool. Women candidates tended to evaluate social media as more important and more useful than did male candidates, particularly in terms of party-centered campaign approaches. During the election campaign, however, women candidates did not use Twitter more or differently did than men. The logic of election campaigning makes candidates act in more predictable ways. The highest-ranked candidates and the incumbents were generally the most active; however, we observed that more senior 
candidates became more active during the election campaign, but lost their interest after the election was over. Between the elections, we could see gender patterns for how men and women interacted using Twitter. This pattern has implications for the interpretation of so-called permanent campaigning (see Farrell, 1996) and the logic of online campaigning. During the intense campaign period, the level of activity rose as can be expected, but from these theoretical perspectives, the rationale for social media usage appeared to yield unexpected differences between elections. A distinct normalized or equalized pattern in online campaigning appears difficult to argue for and as this study show, this especially holds true when considering the period between elections. It would appear that the more experienced and routine candidates value social media to a greater extent, judging by their activity and interactivity during the intense campaign period. This indicates a normalized pattern emerging on social media; however, the pattern was not consistent between elections, where we additionally found that female candidates were more prominent in their use.

The normalization/equalization dichotomy provides a limited understanding of the patterns of social media use in this case. Indicators of equalization, like gender, offer inadequate explanatory power in a relatively equal setting. In a context of equal representation in parliament but with existing gender differences in de facto political power, it is not unambiguous how a pattern of more extensive social media use by women politicians should best be understood. It could be argued that social media in this case provides more equal conditions but the results from this use can still resemble a normalized pattern. It would be valuable if future references to this rather dated theory provided more elaborate attempts to explain why social media represents a breaking point or continuation of previous conditions. This could be done by, for example, considering different electoral settings, and campaign vs. non-campaign periods. As this article 
shows, the concept of normalization appears to hold true when looking at a period of intense campaigning, whereas the regular day-to-day basis of political communication on social media platforms indicates a break from this pattern.

Research has shown that women and men were similar in their general campaign styles (Bystrom and Kaid, 2002), as well as in their overall online activity in the recent European elections. Our results suggest that gender does play a role in social media campaigns, which calls for further comparative research in different electoral contexts and with varying degrees of descriptive representation. This study provides insight into the evolution of campaign practices in a context with a relatively gender-equal representation, as well as showing the ability of candidates to adopt and adapt to new media environments. In this regard, social media is seen as an important platform for individual candidates, and its importance can be expected to increase over time. According to Lilleker, Tenscher and Štětka (2015), indications of development towards a "hypermedia" campaign style can be found in the integration and involvement of several platforms as professional campaigning strategies in Europe. As the European campaign structure has developed towards campaign professionalism, this pattern can help to explain the emphasis put on social media campaigning. Separating practices as strategic choices that influence the decision of a more permanent presence as an indication of permanent campaigning is necessary, however (Tenscher, 2013). In line with this reasoning, our results could also indicate that a more strategic use of social media entails a less active presence outside the campaign period. To better understand election campaigns online, we should therefore also study what the candidates are doing between elections. This is perhaps especially true for social media, and such research is necessary to further assess whether social media is used as a professional 
tool for a more permanent online presence or merely as a temporary additional platform during electoral campaigns.

It has been suggested that, in their effort to sidestep traditional media, female candidates aim to project an image of a more open, personal and interactive politician (Carlson et al., 2014). The extent to which this could be linked to a typical female conversational style online may be relevant to study, given that some previous research indicates dissimilar gendered behavior on social media and women in general tend to use technology differently than men (e.g., more sociably; Cunha, Magno, Goncalves, Cambraia and Almeida, 2014; Lasorsa, 2012; Tufekci, 2008; Walton and Rice, 2013). Given the results presented in this article, gender should be studied in greater detail in relation to the political use of social media platforms. Sweden has one of the highest voter turnouts in European elections and the gender distribution of candidates is one of the most equal; nevertheless, we can detect gendered campaigning. These findings should therefore be expected to be even more prominent in other contexts. In contrast to American and British majority election, candidate-centered systems, Sweden's pluralistic, party-centered parliamentary system can provide different implications for individual online campaigning practices. Research has also suggested that being online has a significant effect on intra-party competition (Hansen and Kosiara-Pedersen, 2014). In contrast, the relationship between gender and social media practices in this case may not be as strong in the context of national elections, because the European election possibly presents other opportunities for less-established candidates, such as younger female contenders.

The social media use of political candidates can positively affect interaction with voters and possibly yield additional preferential votes (Spierings and Jacobs, 2014). A relevant issue to address in future research could also be the extent to which a candidate's individual 
characteristics, such as gender, make that candidate more or less likely to benefit from using social media as a campaign strategy. If women candidates succeed in establishing themselves online and using social media to connect to voters - especially female voters, who are more likely to assess female politicians positively (Kosiara-Pedersen and Hansen, 2015) - this could in time strengthen the status of younger women candidates in the electoral system. 


\section{Reference list}

Barber, B. (2001). The Uncertainty of Digital Politics. Harvard International Review, 23 (1), 4247.

Barber, B. (2003). Strong Democracy: Participatory Politics for a New Age. Berkeley, CA: University of California Press.

Berg, L., and Oscarsson, H. (eds) (2015). 20 år med personval [20 years of preferential voting]. Valforskningsprogrammets rapportserie. Statsvetenskapliga institutionen, Göteborgs universitet.

Bimber, B., and Davis, R. (2003). Campaigning Online: The Internet in U.S. Elections. New York: Oxford University Press.

Blombäck, S., and de Fine Licht, J. (2015). Feministiskt initiativs sympatisörer [The sympathizers of Feminist initiative]. In Bergström, A., Johansson, B., Oscarsson, H. and Oskarson, M. (red) Fragment. Göteborgs universitet: SOM-institutet.

Brewer, P. R., Habegger, M., Harrington, R., Hoffman, L. H., Jones, P. E., and Lambe, J. L. (2015). Interactivity Between Candidates and Citizens on a Social Networking Site: Effects on Perceptions and Vote Intentions. Journal of Experimental Political Science, available on CJO2015. doi:10.1017/XPS.2014.29.

Bystrom, D., and Kaid, L. (2002). Are Women Candidates Transforming Campaign Communication: A Comparison of Advertising Videostyles in the 1990s. In C. S. Rosenthal (Ed.), Women Transforming Congress. Norman, OK: University of Oklahoma Press.

Bäck, H., Debus, M., and Müller, J., (2014). Who Takes the Parliamentary Floor? The Role of Gender in Speech-making in the Swedish Riksdag. Political Research Quarterly 67, 504-518.

Carlson, T. (2007). It's a Man's World? Journal of Political Marketing, 6(1), 41-67.

Carlson, T., Djupsund, G., and Strandberg, K. (2014). Taking Risks in Social Media Campaigning: The Early Adoption of Blogging by Candidates. Scandinavian Political Studies, $37,21-40$.

Cook, J. M. (2016). Gender, Party, and Presentation of Family in the Social Media Profiles of 10 State Legislatures. Social Media + Society, 2(2), 1-11.

Cunha, E., Magno, G., Goncalves, M. A., Cambraia, C., and Almeida, V. (2014). He Votes or She Votes? Female and Male Discursive Strategies in Twitter Political Hashtags. Plos One, 9(1).

Dabelko, K. L. C., and Herrnson, P. S. (1997). Women's and Men's Campaigns for the U.S. House of Representatives. Political Research Quarterly 50 (1), 121-35.

Darcy, R., Welch S., and Clark, J. (1994). Women, Elections, and Representation. 2nd ed. Lincoln: University of Nebraska Press. 
Dolan, K. (2005). Do women candidates play to gender stereotypes? Do men candidates play to women? Candidate sex and issues priorities on campaign websites. Political Research Quarterly, $58(1), 31-44$.

Dolan, K. (2010). The Impact of Gender Stereotyped Evaluations on Support for Women Candidates. Political Behavior, 32, 1.

Dolan, K., and Lynch, T. (2016). The Impact of Gender Stereotypes on Voting for Women Candidates by Level and Type of Office. Politics \& Gender, 12(3), 573-595.

Druckman, J., Kifer, M., and Parkin, M. (2007). The Technological Development of Congressional Candidate Web Sites: How and Why Candidates Use Web Innovations. Social Science Computer Review, 25 (4), 425-442.

Ehin, P., and Solvak, M. (2012). Party Voters Gone Astray: Explaining Independent Candidate Success in the 2009 European Elections in Estonia. Journal of Elections, Public Opinion \& Parties, 22(3), 269-291.

Enli, G. and Skogerbø, E. (2013). Personalized Campaigns in Party-centred Politics. Information, Communication and Society, 16(5), 757-774.

Esaiasson, P., and Narud, H. (2013). Between-election Democracy: An Introductory Note. In P. Esaiasson and H. M. Narud (Eds.), Between-election Democracy: The Representative Relationship After Election Day (pp. 1-14). Colchester, UK: ECPR Press.

European Parliament (2013). Women in Decision-making: The Role of the New Media for Increased Political Participation. Directorate General for Internal Policies, Policy Department C: Citizens' Rights and Constitutional Affairs.

Evans, H. K., Cordova, V., and Sipole, S. (2014). Twitter Style: An Analysis of How House Candidates Used Twitter in Their 2012 Campaigns. PS: Political Science and Politics, 47, 454462.

Farrell, D. (1996). Campaign Strategies and Tactics. In L. Leduc, R. G. Niemi, and P. Norris (Eds.), Comparing Democracies (pp. 160-183). London: Sage.

Folke, O., and Rickne, J. (2016). The Glass Ceiling in Politics: Formalization and Empirical Tests. Comparative Political Studies, 49(5), 567-599.

Fox, R. L., and Lawless, J. L. (2011), Gendered Perceptions and Political Candidacies: A Central Barrier to Women's Equality in Electoral Politics. American Journal of Political Science, $55,59-73$.

Freedman, J. (2002). Women in the European Parliament. Parliamentary Affairs, 55(1), 179188. 
Fulton, S. A. (2012). Running Backwards and in High Heels: The Gendered Quality Gap and Incumbent Electoral Success. Political Research Quarterly, 65(2), 303-314.

Gainous, J., and Wagner, K. (2013). Tweeting to Power: The Social Media Revolution in American Politics. New York: NY, Oxford University Press.

Gervais, B. T. (2015). Incivility Online: Affective and Behavioral Reactions to Uncivil Political Posts in a Web-based Experiment. Journal of Information Technology \& Politics, 12(2).

Gibson, R., Lusoli, W., and Ward, S. (2008). The Australian Public and Politics On-line: Reinforcing or Reinventing Representation? Australasian Political Studies Association, 43(1), 111-131.

Gibson, R., and McAllister, I. (2015). Normalising or Equalising Party Competition? Assessing the Impact of the Web on Election Campaigning. Political Studies, 63(3).

Gilljam, M., Karlsson, D., and Sundell, A. (2010). Politik på hemmaplan. Tiotusen fullmäktigeledamöter tycker om demokrati [Politics on the Home Turf: Ten-thousand Councilors Thinking About Politics and Democracy]. Stockholm: SKL Kommentus.

Grant, W. J., Moon B., and Grant, J. B. (2010). Digital Dialogue? Australian Politicians' Use of the Social Network Tool Twitter. Australian Journal of Political Science, 45(4), 579-604.

Gulati, G. J., and Williams, C. B. (2013). Social Media and Campaign 2012: Developments and Trends for Facebook Adoption. Social Science Computer Review, 31(5), 577-588.

Hagen, M., and Mayer, W. (2000). The Modern Politics of Presidential Selection: How Changing the Rules Really Did Change the Game. In W. G. Mayer (Ed.), In Pursuit of the White House 2000: How We Choose Our Presidential Nominees. New York: Chatham House Publishers, 1-55.

Hansen, K. M., and Kosiara-Pedersen, K. (2014). Cyber-campaigning in Denmark: Application and Effects of Candidate Campaigning. Journal of Information Technology \& Politics, 11(2), 206-219.

Harrison, L. (2005). Electoral Systems and Party Strategies in Britain: Women Candidates in the 1999 and 2004 European Parliamentary Elections. Representation, 41(2), 85-95.

Heith, D. (2003). The Lipstick Watch: Media Coverage, Gender and Presidential Campaigns. In R. P. Watson and A. Gordon (Eds.), Anticipating Madam President (pp. 123-130). Boulder, CO: Lynne Rienner.

Hermans, L., and Vergeer, M. (2012). Personalization in E-campaigning: A Cross-national Comparison of Personalization Strategies Used on Candidate Websites of 17 Countries in EP Elections 2009. New Media and Society, 15, 72-92. 
Hindman, M. (2008). The Myth of Digital Democracy. Princeton, NJ: Princeton University Press.

Hogan, R. E. (2007). The Effects of Candidate Gender on Campaign Spending in State Legislative Elections. Social Science Quarterly, 88, 1092-1105.

Jackson, N. A., and Lilleker, D. G. (2009). Building an Architecture of Participation? Political Parties and Web 2.0 in Britain. Journal of Information Technology \& Politics, 6(3), 232-250.

Jackson, N.A., and Lilleker, D.G. (2011). Microblogging, Constituency Service and Impression Management: UK MPs and the Use of Twitter. The Journal of Legislative Studies, 17(1), 86105.

Jacobs, K., and Spierings, N. (2016). Social media, parties, and political inequalities. New York: Palgrave MacMillan.

Jalalzai, F. (2006). Women Candidates and the Media: 1992-2000 Elections. Politics and Policy, $34(3)$.

Jungherr, A. (2014). Twitter in Politics: A Comprehensive Literature Review. Available at SSRN: http://ssrn.com/abstract=2402443 or http://dx.doi.org/10.2139/ssrn.2402443.

Just, M., and Crigler, A. (2014). Gender and Self-Presentation in Social Media: An Analysis of the 10 Most Competitive 2012 U.S. Senate Races. APSA 2014 Annual Meeting Paper. Available at SSRN: http://ssrn.com/abstract=2453741.

Kahn, K. (1996). The Political Consequences of Being a Woman: How Stereotypes Influence the Conduct and Consequences of Political Campaigns. New York: Columbia University Press.

Karlsen, R. (2011). A Platform for Individualized Campaigning? Social Media and Parliamentary Candidates in the 2009 Norwegian Election Campaign. Policy and the Internet, 3.

Karlsen, R., and Enjolras, B. (2016). Styles of Social Media Campaigning and Influence in a Hybrid Political Communication System: Linking Candidate Survey Data with Twitter Data. The International Journal of Press/Politics, 21(3), 338-357.

Kosiara-Pedersen, K., and Hansen, K. M. (2015). Gender Differences in Assessments of Party Leaders. Scandinavian Political Studies, 38, 26-48.

Krook, M. L. (2006). Reforming Representation: The Diffusion of Candidate Gender Quotas Worldwide. Politics \& Gender, 2(3), 303-327.

Larson, S. G. (2001). Running as Women? A Comparison of Female and Male Pennsylvania Assembly Candidates' Campaign Brochures. Women and Politics, 22, 107-124. 
Larsson, A. O., and Kalsnes, B. (2014). "Of Course We Are on Facebook": Use and Non-use of Social Media Among Swedish and Norwegian Politicians. European Journal of Communication, 29(6), 653-667.

Larsson, A. O. (2015a). The EU Parliament on Twitter - Assessing the Permanent Online Practices of Parliamentarians. Journal of Information Technology and Politics, 12(2),149-166.

Larsson, A. O. (2015b). Going Viral? Comparing Parties on Social Media During the 2014 Swedish Election. Convergence: The International Journal of Research into New Media Technologies, 1354856515577891.

Lasorsa, D. (2012). Transparency and Other Journalistic Norms on Twitter the Role of Gender. Journalism Studies, 13(3), 402-417.

Lassen, D., and Brown, A. (2011). Twitter: The Electoral Connection? Social Science Computer Review, 29 (4).

Lilleker, D. G., and Koc-Michalska, K. (2013). Online Political Communication Strategies: MEPs, E-Representation, and Self-Representation. Journal of Information Technology \& Politics, 10(2), 190-207.

Lilleker, D. G., Koc-Michalska K., Schweitzer E. J., Jacunski, M., Jackson, N., and Vedel, T. (2011). Informing, Engaging, Mobilizing or Interacting: Searching for a European Model of Web Campaigning. European Journal of Communication, 26(3), 195-213.

Lilleker, D. G., Tenscher J., and Štětka V. (2015). Towards Hypermedia Campaigning? Perceptions of New Media's Importance for Campaigning by Party Strategists in Comparative Perspective. Information, Communication and Society, 18, 747-765.

Lusoli, W. (2005). The Internet and the European Parliament Elections: Theoretical Perspectives, Empirical Investigations and Proposals for Research. Information Polity, 10(3), 153-163.

Marcinkowski, F., and Metag, J. (2014). Why Do Candidates Use Online Media in Constituency Campaigning? An Application of the Theory of Planned Behavior. Journal of Information Technology and Politics, 11, 151-168.

Margolis, M., and Resnick. D. (2000). Politics as Usual: The Cyberspace Revolution. London: Sage.

Meeks, L. (2013). A Woman's Place: Gender Politics and Twitter in the 2012 Elections. (Unpublished doctoral dissertation). University of Washington, Seattle.

Megarry, J. (2014). Online Incivility or Sexual Harassment? Conceptualizing Women's Experiences in the Digital Age. Women's Studies International Forum, 47(1), 46-55. 
Müller, W.C. (2000). Political Parties in Parliamentary Democracies: Making Delegation and Accountability Work. European Journal of Political Research, 37, 309-33.

Nulty, P., Theocharis, Y., Popa, S. A., Parnet, O., and Benoit, K. (2016). Social Media and Political Communication in the 2014 Elections to the European Parliament. Electoral Studies, 44, 429-444.

Obholzer, L., and Daniel, W. T. (2016). An Online Electoral Connection? How Electoral Systems Condition Representatives' Social Media Use. European Union Politics, 17(3), 387407.

Pearson, K., and McGhee, E. (2013). What It Takes to Win: Questioning "Gender Neutral" Outcomes in US House Elections. Politics \& Gender, 9(4), 439.

Pierre, J. (2015). The Oxford Handbook of Swedish Politics. Oxford: Oxford University Press.

Sapiro, V., Walsh, K.C., Strach, P., and Hennings, V. (2011). Gender, Context, and Television Advertising: A Comprehensive Analysis of 2000 and 2002 House Races. Political Research Quarterly, 64(1), 107-119.

Schmitt, H. (2009). European Parliament Elections After Eastern Enlargement. Journal of European Integration, 31(5), 525-35.

Scully, R., and Farrell, D. (2003). MEPs as Representatives: Individual and Institutional Roles*. JCMS: Journal of Common Market Studies, 41(2), 269-288.

Segaard, S. B., and Nielsen, J. A. (2013). Local Election Blogs: Networking Among the Political Elite. Information Polity 18, 4 (October 2013), 299-313.

Southern, R. (2015). Is Web 2.0 Providing a Voice for Outsiders? A Comparison of Personal Website and Social Media Use by Candidates at the 2010 UK General Election. Journal of Information Technology and Politics, 12(1).

Spierings, N., and Jacobs, K. (2014). Getting Personal? The Impact of Social Media on Preferential Voting. Political Behavior, 36(1), 215-234.

Strandberg, K. (2013). A Social Media Revolution or Just a Case of History Repeating Itself? The Use of Social Media in the 2011 Finnish Parliamentary Elections. New Media and Society, 15(8).

Strömbäck, J. (2008). Four Phases of Mediatization: An Analysis of the Mediatization of Politics. The International Journal of Press/Politics, 13(3), 228-246.

Tenscher, J. (2013). First- and Second-order Campaigning: Evidence from Germany. European Journal of Communication, 28(3), 241-258. 
Tufekci, Z. (2008). Grooming, Gossip, Facebook and Myspace. Information, Communication and Society, 11(4), 544-564.

Utz, S. (2009). The (Potential) Benefits of Campaigning via Social Network Sites. Journal of Computer-Mediated Communication, 14, 221-243.

Vaccari, C. (2013). A Tale of Two E-parties Candidate Websites in the 2008 US Presidential Primaries. Party Politics, 19(1), 19-40.

Vergeer, M., and Hermans, L. (2013). Campaigning on Twitter: Microblogging and Online Social Networking as Campaign Tools in the 2010 General Elections in the Netherlands. Journal of Computer-Mediated Communication, 18(4), 399-419.

Vergeer, M., Hermans, L., and Cunha, C. (2013). Web Campaigning in the 2009 European Parliament Elections: A Cross-national Comparative Analysis. New Media and Society, 15(1), 128-148.

Vergeer, M., Hermans, L., and Sams, S. (2011). Is the Voter Only a Tweet Away? Micro Blogging During the 2009 European Parliament Election Campaign in the Netherlands. First Monday, 16(8).

Walton, S., and Rice, R. (2013). Mediated Disclosure on Twitter: The Roles of Gender and Identity in Boundary Impermeability, Valence, Disclosure, and Stage. Computers in Human Behavior, 29(4), 1465-1474.

Werner, B. (1997). Financing the Campaigns of Women Candidates and Their Opponents: Evidence from Three States, 1982-1990. Women \& Politics, 19, 81-97.

Wängnerud, L. (2015). The Principles of Gender-Sensitive Parliaments. New York: Routledge.

Ward, S., Gibson, R., and Lusoli, W. (2003). Online Participation and Mobilization in Britain: Hype, Hope and Reality. Parliamentary Affairs, 56(4), 652-688. 


\section{Figure 1. Mean importance of campaign activities to candidates in the 2014 European election}

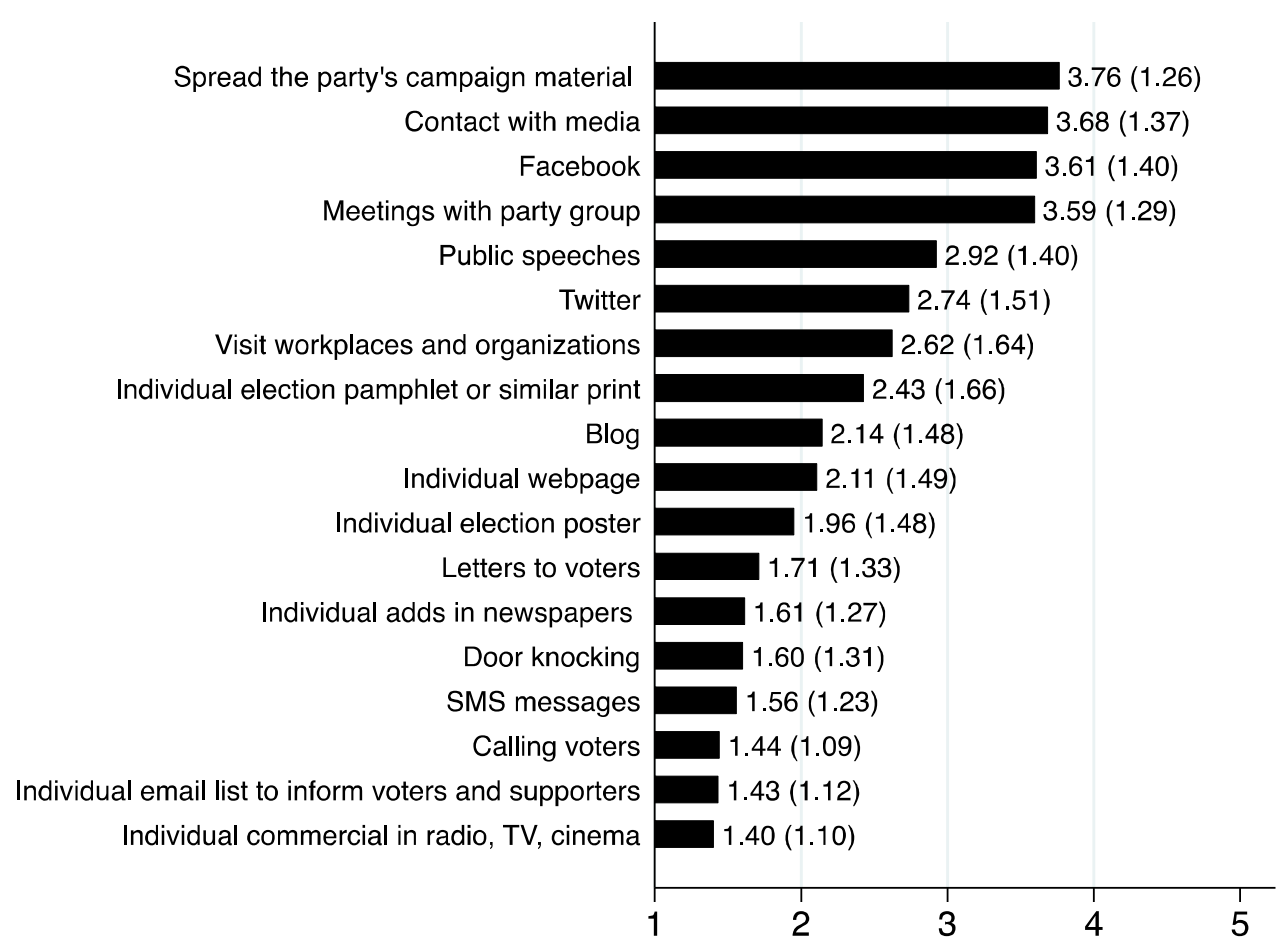

Note: The scale runs from 1 (unimportant) to 5 (very important). Standard deviation within parentheses. 
Table 1. Assessment of importance of campaign activities by candidates in the 2014 European election

\begin{tabular}{|c|c|c|c|c|c|}
\hline & Web-campaign & Traditional & Outreach & Personal & Media \\
\hline \multirow[t]{2}{*}{ Sex (women) } & $0.11 * *$ & $0.08 *$ & -0.06 & $0.09 * *$ & 0.07 \\
\hline & $(0.05)$ & $(0.04)$ & $(0.13)$ & $(0.04)$ & $(0.04)$ \\
\hline \multirow[t]{2}{*}{ Placement on the party list (1-43) } & -0.00 & $-0.00 * * *$ & -0.01 & -0.00 & -0.00 \\
\hline & $(0.00)$ & $(0.00)$ & $(0.01)$ & $(0.00)$ & $(0.00)$ \\
\hline \multirow[t]{2}{*}{ Age (22-83) } & $-0.00 * *$ & $0.00 * *$ & 0.00 & -0.00 & -0.00 \\
\hline & $(0.00)$ & $(0.00)$ & $(0.00)$ & $(0.00)$ & $(0.00)$ \\
\hline \multirow[t]{2}{*}{ Incumbent } & $0.22 * *$ & -0.03 & -0.03 & 0.12 & 0.02 \\
\hline & $(0.11)$ & $(0.11)$ & $(0.31)$ & $(0.09)$ & $(0.10)$ \\
\hline \multirow[t]{2}{*}{ Experience as MP } & -0.02 & -0.08 & -0.04 & -0.04 & -0.07 \\
\hline & $(0.07)$ & $(0.06)$ & $(0.20)$ & $(0.06)$ & $(0.07)$ \\
\hline \multicolumn{6}{|l|}{$\begin{array}{l}\text { Party (Social Democrats are ref. } \\
\text { category ) }\end{array}$} \\
\hline \multirow[t]{2}{*}{ Center Party } & 0.03 & -0.05 & $-0.39 * * *$ & $-0.44 * * *$ & -0.08 \\
\hline & $(0.09)$ & $(0.08)$ & $(0.25)$ & $(0.07)$ & $(0.08)$ \\
\hline \multirow[t]{2}{*}{ Christian Democrats } & 0.03 & -0.05 & -0.33 & $-0.43 * * *$ & -0.13 \\
\hline & $(0.09)$ & $(0.09)$ & $(0.25)$ & $(0.07)$ & $(0.08)$ \\
\hline \multirow{2}{*}{ Conservative Party } & -0.01 & 0.02 & -0.21 & -0.06 & 0.00 \\
\hline & $(0.10)$ & $(0.09)$ & $(0.30)$ & $(0.09)$ & $(0.09)$ \\
\hline \multirow[t]{2}{*}{ Feminist Party } & -0.01 & $-0.30 * *$ & $-0.81 *$ & $-0.66^{* * *}$ & $-0.35 * * *$ \\
\hline & $(0.15)$ & $(0.13)$ & $(0.41)$ & $(0.12)$ & $(0.13)$ \\
\hline \multirow[t]{2}{*}{ Green Party } & 0.03 & -0.12 & $-0.43 *$ & $-0.51 * * *$ & $-0.22 * * *$ \\
\hline & $(0.08)$ & $(0.08)$ & $(0.24)$ & $(0.07)$ & $(0.08)$ \\
\hline \multirow[t]{2}{*}{ Left Party } & $-0.18 * *$ & -0.06 & $-0.86^{* * *}$ & $-0.53 * * *$ & $-0.36^{* * *}$ \\
\hline & $(0.09)$ & $(0.08)$ & $(0.25)$ & $(0.07)$ & $(0.08)$ \\
\hline \multirow[t]{2}{*}{ Liberal Party } & 0.12 & -0.03 & -0.26 & $-0.39 * * *$ & 0.05 \\
\hline & $(0.10)$ & $(0.09)$ & $(0.28)$ & $(0.08)$ & $(0.09)$ \\
\hline \multirow[t]{2}{*}{ Pirate Party } & -0.02 & $-0.21 * *$ & $-0.87 * * *$ & $-0.53 * * *$ & $-0.30 * * *$ \\
\hline & $(0.11)$ & $(0.10)$ & $(0.30)$ & $(0.09)$ & $(0.10)$ \\
\hline \multirow[t]{2}{*}{ Sweden Democrats } & $-0.38 * * *$ & $-0.38 * * *$ & $-1.14 * * *$ & $-0.55 * * *$ & $-0.36 * * *$ \\
\hline & $(0.11)$ & $(0.11)$ & $(0.33)$ & $(0.10)$ & $(0.11)$ \\
\hline \multirow[t]{2}{*}{ Intercept } & $0.57 * * *$ & $0.63 * * *$ & $1.18 * * *$ & $0.65 * * *$ & $0.39 * * *$ \\
\hline & $(0.10)$ & $(0.10)$ & $(0.30)$ & $(0.09)$ & $(0.09)$ \\
\hline $\mathrm{R}^{2}$ & 0.24 & 0.26 & 0.18 & 0.49 & 0.29 \\
\hline $\mathrm{N}$ & 142 & 142 & 137 & 143 & 144 \\
\hline
\end{tabular}


Table 2. Assessment of importance of web campaign activities by candidates in the 2014 European election

\begin{tabular}{|c|c|c|c|c|}
\hline & Twitter & Facebook & Blog & Home page \\
\hline \multirow[t]{2}{*}{ Sex (women) } & $0.14 * *$ & $0.11 * *$ & 0.08 & 0.09 \\
\hline & $(0.06)$ & $(0.05)$ & $(0.06)$ & $(0.06)$ \\
\hline \multirow[t]{2}{*}{ Placement on the party list (1-43) } & -0.00 & -0.00 & 0.00 & -0.00 \\
\hline & $(0.00)$ & $(0.00)$ & $(0.00)$ & $(0.00)$ \\
\hline \multirow[t]{2}{*}{ Age (22-83) } & $-0.01 * * *$ & -0.00 & -0.00 & -0.00 \\
\hline & $(0.00)$ & $(0.00)$ & $(0.00)$ & $(0.00)$ \\
\hline \multirow[t]{2}{*}{ Incumbent } & $0.42 * * *$ & -0.05 & 0.26 & $0.28 *$ \\
\hline & $(0.15)$ & $(0.13)$ & $(0.16)$ & $(0.16)$ \\
\hline \multirow[t]{2}{*}{ Experience as MP } & 0.04 & $-0.16^{*}$ & -0.07 & 0.06 \\
\hline & $(0.10)$ & $(0.08)$ & $(0.10)$ & $(0.10)$ \\
\hline \multicolumn{5}{|c|}{ Party (Social Democrats are ref. category ) } \\
\hline \multirow[t]{2}{*}{ Center Party } & 0.04 & $-0.19^{*}$ & 0.14 & 0.09 \\
\hline & $(0.12)$ & $(0.11)$ & $(0.13)$ & $(0.12)$ \\
\hline \multirow[t]{2}{*}{ Christian Democrats } & -0.05 & -0.05 & 0.17 & 0.02 \\
\hline & $(0.12)$ & $(0.10)$ & $(0.13)$ & $(0.12)$ \\
\hline \multirow[t]{2}{*}{ Conservative Party } & 0.06 & -0.16 & 0.07 & -0.01 \\
\hline & $(0.14)$ & $(0.12)$ & $(0.15)$ & $(0.15)$ \\
\hline \multirow[t]{2}{*}{ Feminist Party } & 0.10 & -0.03 & -0.19 & 0.07 \\
\hline & $(0.20)$ & $(0.18)$ & $(0.21)$ & $(0.21)$ \\
\hline \multirow[t]{2}{*}{ Green Party } & -0.04 & $-0.21 * *$ & 0.21 & 0.16 \\
\hline & $(0.13)$ & $(0.10)$ & $(0.12)$ & $(0.12)$ \\
\hline \multirow[t]{2}{*}{ Left Party } & -0.15 & $-0.40 * * *$ & 0.02 & -0.20 \\
\hline & $(0.12)$ & $(0.10)$ & $(0.12)$ & $(0.12)$ \\
\hline \multirow[t]{2}{*}{ Liberal Party } & 0.15 & -0.05 & $0.29^{*}$ & 0.21 \\
\hline & $(0.13)$ & $(0.12)$ & $(0.14)$ & $(0.14)$ \\
\hline \multirow[t]{2}{*}{ Pirate Party } & -0.08 & $-0.35 * *$ & $0.26^{*}$ & 0.09 \\
\hline & $(0.14)$ & $(0.13)$ & $(0.15)$ & $(0.15)$ \\
\hline \multirow[t]{2}{*}{ Sweden Democrats } & $-0.36^{* *}$ & $-0.79 * * *$ & -0.11 & -0.23 \\
\hline & $(0.16)$ & $(0.14)$ & $(0.17)$ & $(0.17)$ \\
\hline \multirow[t]{2}{*}{ Intercept } & $0.81 * * *$ & 0.97 & 0.20 & $0.30 * *$ \\
\hline & $(0.14)$ & $(0.12)$ & $(0.15)$ & $(0.14)$ \\
\hline $\mathrm{R}^{2}$ & 0.25 & 0.32 & 0.12 & 0.17 \\
\hline $\mathrm{N}$ & 144 & 148 & 147 & 147 \\
\hline
\end{tabular}


Table 3. Assessment of importance of Twitter for personal or party centered purposes and evaluation of the use of Twitter for these purposes in the candidates' campaign

\begin{tabular}{|c|c|c|c|c|}
\hline & \multicolumn{2}{|c|}{ Twitter Motivation } & \multicolumn{2}{|c|}{ Twitter Evaluation } \\
\hline & Personal & Party & Personal & Party \\
\hline \multirow[t]{2}{*}{ Sex (women) } & $0.12 * *$ & $0.18 * * *$ & 0.05 & $0.13 *$ \\
\hline & $(0.06)$ & $(0.06)$ & $(0.06)$ & $(0.07)$ \\
\hline \multirow[t]{2}{*}{ Placement on the party list (1-43) } & -0.00 & -0.00 & -0.00 & 0.00 \\
\hline & $(0.00)$ & $(0.00)$ & $(0.00)$ & $(0.00)$ \\
\hline \multirow[t]{2}{*}{ Age (22-83) } & -0.00 & 0.00 & -0.00 & -0.00 \\
\hline & $(0.00)$ & $(0.00)$ & $(0.00)$ & $(0.00)$ \\
\hline \multirow{2}{*}{ Incumbent } & 0.10 & -0.11 & 0.20 & 0.10 \\
\hline & $(0.13)$ & $(0.14)$ & $(0.13)$ & $(0.15)$ \\
\hline \multirow[t]{2}{*}{ Experience as MP } & -0.08 & $-0.19^{*}$ & 0.07 & -0.03 \\
\hline & $(0.13)$ & $(0.10)$ & $(0.10)$ & $(0.11)$ \\
\hline \multicolumn{5}{|c|}{ Party (Social Democrats are ref. category) } \\
\hline \multirow[t]{2}{*}{ Center Party } & 0.18 & 0.02 & 0.16 & -0.03 \\
\hline & $(0.12)$ & $(0.13)$ & $(0.13)$ & $(0.13)$ \\
\hline \multirow[t]{2}{*}{ Christian Democrats } & 0.14 & 0.15 & 0.16 & 0.06 \\
\hline & $(0.12)$ & $(0.13)$ & $(0.13)$ & $(0.14)$ \\
\hline \multirow[t]{2}{*}{ Conservative Party } & 0.07 & 0.01 & 0.03 & -0.18 \\
\hline & $(0.12)$ & $(0.13)$ & $(0.13)$ & $(0.14)$ \\
\hline \multirow[t]{2}{*}{ Feminist Party } & -0.01 & 0.02 & 0.14 & 0.20 \\
\hline & $(0.18)$ & $(0.20)$ & $(0.19)$ & $(0.20)$ \\
\hline \multirow[t]{2}{*}{ Green Party } & 0.02 & -0.02 & 0.04 & -0.21 \\
\hline & $(0.11)$ & $(0.12)$ & $(0.12)$ & $(0.12)$ \\
\hline \multirow[t]{2}{*}{ Left Party } & $-0.28 * *$ & 0.05 & -0.19 & -0.22 \\
\hline & $(0.11)$ & $(0.12)$ & $(0.13)$ & $(0.13)$ \\
\hline \multirow[t]{2}{*}{ Liberal Party } & 0.12 & -0.03 & -0.04 & -0.19 \\
\hline & $(0.12)$ & $(0.13)$ & $(0.13)$ & $(0.14)$ \\
\hline \multirow[t]{2}{*}{ Pirate Party } & -0.16 & -0.03 & -0.19 & -0.20 \\
\hline & $(0.13)$ & $(0.15)$ & $(0.14)$ & $(0.15)$ \\
\hline \multirow[t]{2}{*}{ Sweden Democrats } & -0.06 & 0.01 & 0.08 & -0.04 \\
\hline & $(0.21)$ & $(0.23)$ & $(0.22)$ & $(0.24)$ \\
\hline Intercept & $\begin{array}{l}0.58 * * * \\
(0.14)\end{array}$ & $\begin{array}{l}0.54 * * * \\
(0.15)\end{array}$ & $\begin{array}{l}0.52^{* * * *} \\
(0.15)\end{array}$ & $\begin{array}{l}0.53^{* * * *} \\
(0.16)\end{array}$ \\
\hline Observations & 92 & 91 & 88 & 88 \\
\hline R-squared & 0.28 & 0.19 & 0.24 & 0.22 \\
\hline
\end{tabular}


Table 4. Activity on Twitter during and after the election campaign (NBREG)

\begin{tabular}{|c|c|c|c|c|c|c|}
\hline & $\begin{array}{c}2014 \\
\text { Number of } \\
\text { tweets }\end{array}$ & $\begin{array}{c}2014 \\
\text { Twitter } \\
\text { interactions }\end{array}$ & $\begin{array}{c}2014 \\
\text { Twitter } \\
\text { information }\end{array}$ & $\begin{array}{c}2015 \\
\text { Number of } \\
\text { tweets }\end{array}$ & $\begin{array}{c}2015 \\
\text { Twitter } \\
\text { interactions }\end{array}$ & $\begin{array}{c}2015 \\
\text { Twitter } \\
\text { information }\end{array}$ \\
\hline Sex (women) & $\begin{array}{c}0.15 \\
(0.18)\end{array}$ & $\begin{array}{c}0.13 \\
(0.21)\end{array}$ & $\begin{array}{c}0.22 \\
(0.19)\end{array}$ & $\begin{array}{l}0.47 * * \\
(0.20)\end{array}$ & $\begin{array}{l}0.46^{* *} \\
(0.23)\end{array}$ & $\begin{array}{l}0.26 \\
(0.21)\end{array}$ \\
\hline Placement on the party list (1-43) & $\begin{array}{l}-0.02 * \\
(0.01)\end{array}$ & $\begin{array}{l}-0.02 * \\
(0.01)\end{array}$ & $\begin{array}{l}-0.01 * \\
(0.01)\end{array}$ & $\begin{array}{l}-0.02 * \\
(0.01)\end{array}$ & $\begin{array}{l}-0.02 \\
(0.01)\end{array}$ & $\begin{array}{l}-0.01 \\
(0.01)\end{array}$ \\
\hline Age (22-83) & $\begin{array}{l}-0.02 * * \\
(0.01)\end{array}$ & $\begin{array}{l}-0.02 * * \\
(0.01)\end{array}$ & $\begin{array}{l}-0.01 * \\
(0.01)\end{array}$ & $\begin{array}{l}-0.03 * * * \\
(0.01)\end{array}$ & $\begin{array}{l}-0.03^{* * *} \\
(0.01)\end{array}$ & $\begin{array}{c}-0.02 * * \\
(0.01)\end{array}$ \\
\hline Incumbent & $\begin{array}{l}0.98 * * \\
(0.38)\end{array}$ & $\begin{array}{l}1.03 * * \\
(0.44)\end{array}$ & $\begin{array}{l}1.19 * * * \\
(0.40)\end{array}$ & $\begin{array}{l}0.96 * * \\
(0.47)\end{array}$ & $\begin{array}{l}1.06 \\
(0.54)\end{array}$ & $\begin{array}{c}1.23 \\
(0.47)\end{array}$ \\
\hline Experience as MP & $\begin{array}{l}0.60^{* *} \\
(0.26)\end{array}$ & $\begin{array}{l}0.82 * * * \\
(0.31)\end{array}$ & $\begin{array}{l}0.37 \\
(0.27)\end{array}$ & $\begin{array}{c}0.35 \\
(0.29)\end{array}$ & $\begin{array}{c}0.42 \\
(0.33)\end{array}$ & $\begin{array}{c}0.30 \\
(0.29)\end{array}$ \\
\hline \multicolumn{7}{|l|}{$\begin{array}{l}\text { Party (Social Democrats are ref. } \\
\text { category ) }\end{array}$} \\
\hline Center Party & $\begin{array}{c}0.40 \\
(0.36)\end{array}$ & $\begin{array}{c}0.24 \\
(0.43)\end{array}$ & $\begin{array}{c}0.25 \\
(0.36)\end{array}$ & $\begin{array}{l}1.39 * * * \\
(0.45)\end{array}$ & $\begin{array}{l}1.52 * * \\
(0.51)\end{array}$ & $\begin{array}{l}0.99 * \\
(0.47)\end{array}$ \\
\hline Christian Democrats & $\begin{array}{c}0.08 \\
(0.35)\end{array}$ & $\begin{array}{l}-0.17 \\
(0.39)\end{array}$ & $\begin{array}{c}0.12 \\
(0.35)\end{array}$ & $\begin{array}{c}0.64 \\
(0.45)\end{array}$ & $\begin{array}{c}0.74 \\
(0.51)\end{array}$ & $\begin{array}{c}0.32 \\
(0.45)\end{array}$ \\
\hline Conservative Party & $\begin{array}{c}0.25 \\
(0.36)\end{array}$ & $\begin{array}{c}0.08 \\
(0.42)\end{array}$ & $\begin{array}{c}0.34 \\
(0.36)\end{array}$ & $\begin{array}{l}-0.05 \\
(0.44)\end{array}$ & $\begin{array}{l}-0.21 \\
(0.50)\end{array}$ & $\begin{array}{l}-0.02 \\
(0.45)\end{array}$ \\
\hline Feminist Party & $\begin{array}{l}0.97 * \\
(0.55)\end{array}$ & $\begin{array}{c}0.65 \\
(0.59)\end{array}$ & $\begin{array}{c}0.11 \\
(0.55)\end{array}$ & $\begin{array}{l}-0.71 \\
(0.68)\end{array}$ & $\begin{array}{l}-0.77 \\
(0.78)\end{array}$ & $\begin{array}{l}-0.86 \\
(0.68)\end{array}$ \\
\hline Green Party & $\begin{array}{c}0.49 \\
(0.33)\end{array}$ & $\begin{array}{c}0.47 \\
(0.39)\end{array}$ & $\begin{array}{c}0.50 \\
(0.34)\end{array}$ & $\begin{array}{c}0.35 \\
(0.43)\end{array}$ & $\begin{array}{c}0.52 \\
(0.48)\end{array}$ & $\begin{array}{c}0.21 \\
(0.43)\end{array}$ \\
\hline Left Party & $\begin{array}{l}0.59 \\
(0.37)\end{array}$ & $\begin{array}{c}0.47 \\
(0.44)\end{array}$ & $\begin{array}{c}0.49 \\
(0.38)\end{array}$ & $\begin{array}{l}1.06 * * \\
(0.47)\end{array}$ & $\begin{array}{l}1.25^{*} \\
(0.53)\end{array}$ & $\begin{array}{c}0.81 * \\
(0.47)\end{array}$ \\
\hline Liberal Party & $\begin{array}{c}0.21 \\
(0.34)\end{array}$ & $\begin{array}{c}0.17 \\
(0.39)\end{array}$ & $\begin{array}{l}0.27 \\
(0.35)\end{array}$ & $\begin{array}{c}0.86^{*} \\
(0.44)\end{array}$ & $\begin{array}{l}1.22 * * \\
(0.50)\end{array}$ & $\begin{array}{c}0.58 \\
(0.44)\end{array}$ \\
\hline Pirate Party & $\begin{array}{l}0.77^{*} \\
(0.41)\end{array}$ & $\begin{array}{c}0.55 \\
(0.47)\end{array}$ & $\begin{array}{l}0.81 * * \\
(0.41)\end{array}$ & $\begin{array}{c}0.83 \\
(0.51)\end{array}$ & $\begin{array}{l}1.12 * \\
(0.57)\end{array}$ & $\begin{array}{c}0.64 \\
(0.52)\end{array}$ \\
\hline Sweden Democrats & $\begin{array}{l}-0.57 \\
(0.49)\end{array}$ & $\begin{array}{l}-0.20 \\
(0.56)\end{array}$ & $\begin{array}{l}-0.39 \\
(0.51)\end{array}$ & $\begin{array}{l}-0.18 \\
(0.57)\end{array}$ & $\begin{array}{c}0.08 \\
(0.64)\end{array}$ & $\begin{array}{l}-0.42 \\
(0.58)\end{array}$ \\
\hline Intercept & $\begin{array}{l}5.62 * * * \\
(0.44) \\
\end{array}$ & $\begin{array}{l}5.11 * * * \\
(0.51)\end{array}$ & $\begin{array}{l}5.25^{* * * *} \\
(0.45)\end{array}$ & $\begin{array}{l}5.75^{* * * *} \\
(0.52) \\
\end{array}$ & $\begin{array}{l}5.10^{* * *} \\
(0.58) \\
\end{array}$ & $\begin{array}{l}5.25^{* * * *} \\
(0.53)\end{array}$ \\
\hline Pseudo $\mathrm{R}^{2}$ & 0.01 & 0,01 & 0.01 & 0.02 & 0.02 & 0.01 \\
\hline $\mathrm{N}$ & 196 & 196 & 196 & 195 & 195 & 195 \\
\hline
\end{tabular}

Standard error in parentheses $* * * \mathrm{p}<0.01,{ }^{* *} \mathrm{p}<0.05,{ }^{*} \mathrm{p}<0.1$ 
2

\section{Appendix 1}

Table A1. Campaign activities. Factor analysis (Principal Component)

\begin{tabular}{|c|c|c|c|c|c|}
\hline & Traditional & Web campaign & Outreach & Personal & Media \\
\hline Meetings with party group & 0.80 & & & & \\
\hline Contact with media & 0.72 & & & & \\
\hline Spread the party's campaign material & 0.70 & & & & \\
\hline Public speeches & 0.59 & & & & \\
\hline $\begin{array}{l}\text { Blog } \\
\text { Individual webpage } \\
\text { Twitter } \\
\text { Facebook }\end{array}$ & & $\begin{array}{l}0.83 \\
0.81 \\
0.59 \\
0.56\end{array}$ & & & \\
\hline $\begin{array}{l}\text { Calling voters } \\
\text { SMS messages } \\
\text { Individual email list to inform voters } \\
\text { and supporters } \\
\text { Visit workplaces and organizations }\end{array}$ & & & $\begin{array}{l}0.73 \\
0.72 \\
0.59 \\
\\
0.57\end{array}$ & & \\
\hline $\begin{array}{l}\text { Door knocking } \\
\text { Letters to voters } \\
\text { Individual election poster }\end{array}$ & & & & $\begin{array}{l}0.75 \\
0.72 \\
0.70\end{array}$ & \\
\hline $\begin{array}{l}\text { Individual commercial in radio, TV, } \\
\text { cinema } \\
\text { Individual adds in newspaper } \\
\text { Individual election pamphlet or } \\
\text { similar print }\end{array}$ & & & & & $\begin{array}{l}0.75 \\
0.70 \\
0.62\end{array}$ \\
\hline Eigenvalue (initial) & 4.45 & 2.34 & 1.55 & 1.52 & 1.11 \\
\hline
\end{tabular}




\section{Appendix 2}

Table A2. Gender and Activity on Twitter, February 2013 (NBREG)

\begin{tabular}{|c|c|c|c|}
\hline & $\begin{array}{c}2013 \\
\text { Number of tweets }\end{array}$ & $\begin{array}{c}2013 \\
\text { Twitter interactions } \\
\end{array}$ & $\begin{array}{c}2013 \\
\text { Twitter information }\end{array}$ \\
\hline Sex (women) & $\begin{array}{l}0.91 * * * \\
(0.31)\end{array}$ & $\begin{array}{l}1.02 * * * \\
(0.36)\end{array}$ & $\begin{array}{l}0.83 * * * \\
(0.31)\end{array}$ \\
\hline Placement on the party list (1-43) & $\begin{array}{l}-0.02 \\
(0.02)\end{array}$ & $\begin{array}{l}-0.01 \\
(0.02)\end{array}$ & $\begin{array}{l}-0.02 \\
(0.02)\end{array}$ \\
\hline Age (22-83) & $\begin{array}{c}-0.02 * * \\
(0.01)\end{array}$ & $\begin{array}{l}-0.03 * * * \\
(0.01)\end{array}$ & $\begin{array}{l}-0.02 * \\
(0.01)\end{array}$ \\
\hline Incumbent & $\begin{array}{l}-0.11 \\
(0.62)\end{array}$ & $\begin{array}{l}-0.11 \\
(0.75)\end{array}$ & $\begin{array}{l}-0.12 \\
(0.62)\end{array}$ \\
\hline Experience as MP & $\begin{array}{l}-0.90 * * \\
(0.45)\end{array}$ & $\begin{array}{l}-0.73 \\
(0.54)\end{array}$ & $\begin{array}{l}-0.98 * * \\
(0.45)\end{array}$ \\
\hline $\begin{array}{l}\text { Party (Social Democrats are ref. } \\
\text { category ) }\end{array}$ & & & \\
\hline Center Party & $\begin{array}{c}0.90^{*} \\
(0.54)\end{array}$ & $\begin{array}{c}0.93 \\
(0.64)\end{array}$ & $\begin{array}{l}0.89^{*} \\
(0.53)\end{array}$ \\
\hline Christian Democrats & $\begin{array}{l}-0.12 \\
(0.53)\end{array}$ & $\begin{array}{l}-0.39 \\
(0.62)\end{array}$ & $\begin{array}{c}0.15 \\
(0.54)\end{array}$ \\
\hline Conservative Party & $\begin{array}{l}1.11 * \\
(0.65)\end{array}$ & $\begin{array}{c}0.67 \\
(0.77)\end{array}$ & $\begin{array}{l}1.38 * * \\
(0.64)\end{array}$ \\
\hline Feminist Party & $\begin{array}{l}-0.42 \\
(1.04)\end{array}$ & $\begin{array}{l}-0.36 \\
(1.23)\end{array}$ & $\begin{array}{l}-0.43 \\
(1.04)\end{array}$ \\
\hline Green Party & $\begin{array}{l}0.18 \\
(0.49)\end{array}$ & $\begin{array}{c}0.15 \\
(0.59)\end{array}$ & $\begin{array}{c}0.20 \\
(0.50)\end{array}$ \\
\hline Left Party & $\begin{array}{l}0.60 \\
(0.57)\end{array}$ & $\begin{array}{c}0.43 \\
(0.69)\end{array}$ & $\begin{array}{c}0.76 \\
(0.57)\end{array}$ \\
\hline Liberal Party & $\begin{array}{c}0.74 \\
(0.56)\end{array}$ & $\begin{array}{c}0.90 \\
(0.67)\end{array}$ & $\begin{array}{c}0.64 \\
(0.56)\end{array}$ \\
\hline Pirate Party & $\begin{array}{c}0.74 \\
(0.64)\end{array}$ & $\begin{array}{c}0.77 \\
(0.76)\end{array}$ & $\begin{array}{c}0.75 \\
(0.63)\end{array}$ \\
\hline Sweden Democrats & $\begin{array}{l}1.73^{* *} \\
(0.70)\end{array}$ & $\begin{array}{l}2.20 * * * \\
(0.82)\end{array}$ & $\begin{array}{c}1.06 \\
(0.72)\end{array}$ \\
\hline Intercept & $\begin{array}{l}4.34 * * * \\
(0.62)\end{array}$ & $\begin{array}{l}3.69 * * * \\
(0.71)\end{array}$ & $\begin{array}{l}3.71 * * * \\
(0.64)\end{array}$ \\
\hline $\begin{array}{l}\text { Pseudo R-squared } \\
\mathrm{N}\end{array}$ & $\begin{array}{l}0.02 \\
101\end{array}$ & $\begin{array}{l}0,03 \\
101\end{array}$ & $\begin{array}{l}0.02 \\
101\end{array}$ \\
\hline
\end{tabular}

Standard error in parentheses $* * * \mathrm{p}<0.01, * * \mathrm{p}<0.05, * \mathrm{p}<0.1$ 


\section{Appendix 3. Descriptive statistics}

Table A3. Response rate per party (\%)

Table A4. Response rate per age groups (\%)

\begin{tabular}{lll}
\hline Age groups & Statistics Sweden & The survey \\
\hline $18-29$ & 17 & 16 \\
$30-49$ & 46 & 41 \\
$50-64$ & 30 & 30 \\
$65+$ & 8 & 13
\end{tabular}

\begin{tabular}{ll}
\hline Political party & Response rate \\
\hline Center Party & 47 \\
Christian Democrats & 47 \\
Conservative Party & 30 \\
Feminist Party & 44 \\
Green Party & 60 \\
Left Party & 51 \\
Liberal Party & 29 \\
Pirate Party & 45 \\
Social Democrats & 53 \\
Sweden Democrats & 35
\end{tabular}

Note: The statistics are taken from Statistic Sweden's web page: http://www.scb.se/sv /Hitta-statistik/Statistik-efteramne/Demokrati/Allmanna-val/Europaparlamentsval-nominerade-och-valda/\#c undefined

Table A5. Response rate and gender (\%)

\begin{tabular}{lll}
\hline Gender & Statistics Sweden & The survey \\
\hline Women & 47 & 51 \\
& & \\
\hline $\begin{array}{l}\text { Note: The statistics are taken from Statistic Sweden's web page: } \\
\text { amttp://www.scb.se/sv /Hitta-statistik/Statistik-efter- }\end{array}$
\end{tabular}




\section{Appendix 4 Questionnaire}

\section{Importance of campaign activities}

"Were any of the following activities part of your campaign? And if yes, how important were they? Items:"

(A) Door-knocking, canvassing

(B) Distributing party campaign material

(C) Calling up voters on the phone

(D) Visiting businesses and social organizations

(E) Meetings with party elites/members and/or party groups

(F) Media activities (interviews, press releases)

(G) Public speeches and rallies

(H) Personal campaign posters

(I) Direct mailing

(J) Personal newspaper adds

(K) Personal spots in radio, TV, movie houses

(L) Personal flyers or other campaign material (give-aways)

(M) Personal website

(N) Mailing list to inform supporters and voters about mycampaign

(O) Own blog

(P) Facebook

(Q) SMS

(R) Twitter

(S) Other, please specify:

Response options:

(1) little important

(2) somewhat important

(3) very important

(4) most important 
1

2

3

4

5

6

7

8

9

10

11

12

13

14

15

16

17

18

19

20

21

22

23

24

25

26

27

28

29

30

31

32

33

34

35

36

37

38

39

40

41

42

43

44

45

46

47

48

49

50

51

52

53

54

55

56

57

58

59

60

\section{Importance of Twitter}

"How important was Twitter for you when it comes to:"
(A) Tell people about your daily activities as a politician
(B) Disseminate information of the party's daily activities
(C) Be able to show a more personal side of yourself
(D) Getting into personal contact with voters
(E) Visualizing your personal views
(F) Highlighting the party's positions
(G) Debating with political opponents
(H) Criticize political opponents
(I) Reach out to as many voters as possible
(J) Have an impact on traditional media

Response options:

1 - To very low extent, 7- To a very high extent

\section{Evaluations of Twitter}

"To what extent have you been succeeded through Twitter to:

(A) Tell people about your daily activities as a politician

(B) Disseminate information of the party's daily activities

(C) Be able to show a more personal side of yourself

(D) Getting into personal contact with voters

(E) Visualizing your personal views

(F) Highlighting the party's positions

(G) Debating with political opponents

(H) Criticize political opponents

(I) Reach out to as many voters as possible

(J) Have an impact on traditional media

1 - To very low extent, 7- To a very high extent 